\title{
ERGATIVITY IN AUSTRONESIAN LANGUAGES
}

\author{
ILEANA PAUL AND LISA TRAVIS
}

\section{UNIVERSITY OF WESTERN ONTARIO AND MCGILL UNIVERSITY}

Within the Austronesian family, many languages are classified as ergative (e.g., Samoan) or as having some ergative properties (e.g., Tagalog). For one particular language to exhibit some but not all of the characteristics of ergativity is problematic for an ergativity macroparameter. The same issue arises when looking at these languages from an accusative perspective: how do we account for the ergative properties (e.g., Schachter's (1976) two subjects: Topic and Actor). One current proposal is that these languages have A-bar subjects (Richards 2000; Pearson 2001). By classifying a language as ergative or as A-bar, what do we predict? We compare the two approaches as they apply to Malagasy (and to a lesser degree, Tagalog) as a first step in answering this question.

We begin with the ergative analysis, according to which the so-called Topic is the absolutive NP and the Actor is the ergative NP (see, e.g., Bittner and Hale 1996 and Maclachlan 1996). To make the ergative approach fit with the Malagasy and Tagalog facts, it is best supplemented with the exceptional accusative case, rather than a true antipassive construction. The advantages of this approach are many: we can account for the syntactic prominence of the Ergative-Actor (for control, binding and imperatives) and the famous restriction on extraction to Absolutive-Topics. There are, however, problems with the ergative approach, beginning with the nature of the antipassive (verbal morphology, the term status of the object). Setting aside this problem (resolved with the exceptional accusative case), there remains the lack of weak crossover. Unlike in ergative languages, a quantified NP in the Absolutive-Topic position can bind a pronoun embedded in the Ergative-Actor position.

(1) a. [Novangian'ny rainy $\left.{ }_{i}\right]$ ny mpianatra tsirairay $y_{i}$ omaly. PST.TT.visit.DET father.3 DET student each yesterday 'His father visited each student yesterday.' [Malagasy, from Pearson 2001]
b.*? Nor maite du who.ABS love AUX.3SA $/ 3 \mathrm{sE}$ his mother.ERG 'Who does his $_{\mathrm{i}}$ mother love?' [Basque, from Bobaljik 1993]

Thus although both Malagasy and Tagalog have certain ergative properties, they do not pattern uniformly as ergative.

One solution to this mismatch is the Abar analysis (Richards 2000, Sells 2000, Pearson 2001). According to this approach the Topic NP is indeed a topic, along the lines of Germanic languages, while the Actor is the "subject." The Abar analysis can account for the same range of prominence facts as the ergative analysis, without appealing to any exceptional accusative case. Moreover, the lack of weak crossover in (1a) can be explained by appealing to "weakest crossover" (Lasnik and Stowell 1991). The disadvantages with the A-bar analysis lie in the verbal morphology and case alternations, which are not usually found in topicalization. One possible reply to this objection is that the verbal morphology is wh- agreement (Pearson 2001).

A third analysis of Malagasy and Tagalog is the nominative-accusative analysis, as proposed in Guilfoyle, Hung, and Travis 1992. The Topic is a regular A subject position, and the Actor receives exceptional genitive case within the VP. This analysis accounts for 
the verbal morphology and case, but must provide a special account for the syntactic prominence of the Actor and the extraction restriction.

We summarize the three analyses in the table below.

\begin{tabular}{|c|c|c|c|c|}
\hline & \multicolumn{2}{|c|}{ ERGATIVE } & \multirow[t]{2}{*}{$A^{\prime}$} & \multirow[t]{2}{*}{ Nom/Acc } \\
\hline & antipass & $\mathrm{w} / \mathrm{Acc}$ & & \\
\hline \multirow{7}{*}{$\begin{array}{l}\text { Verbal morphology } \\
\text { Object status } \\
\text { Weak crossover } \\
\text { Optionality of Actor? } \\
\text { Case/AGR with Topic } \\
\text { Binding/Control/Imperatives } \\
\text { Extraction }\end{array}$} & $?$ & $\sqrt{ }$ & $?$ & $\sqrt{ }$ \\
\hline & $?$ & $\sqrt{ }$ & $\sqrt{ }$ & $\sqrt{ }$ \\
\hline & \multicolumn{2}{|c|}{$?$} & $\sqrt{ }$ & $\sqrt{ }$ \\
\hline & \multicolumn{2}{|c|}{$?$} & $\sqrt{ }$ & $\sqrt{ }$ \\
\hline & \multicolumn{2}{|c|}{$\sqrt{ }$} & $?$ & $\sqrt{ }$ \\
\hline & \multicolumn{2}{|c|}{$\sqrt{ }$} & $\sqrt{ }$ & $?$ \\
\hline & \multicolumn{2}{|c|}{$\sqrt{ }$} & $\sqrt{ }$ & $?$ \\
\hline
\end{tabular}

Within the shaded area in the table, the facts aren't quite as neat as they appear. In other words, extraction can sometimes occur over the Topic (Cena 1979). And control and binding are not uniformly sensitive to the Actor (Kroeger 1993, Travis 1998). Does this mean that in certain constructions, Tagalog/Malagasy is no longer ergative or no longer has an A-bar subject? Or are these mere exceptions that will naturally fall outside any principled account?

In concluding, we hope to have shown that all three analyses can benefit by comparison with the others. And we hope that this will lead to predicting which "ergative" properties will occur in "mixed" languages like Malagasy and Tagalog.

\section{REFERENCES}

BITTNER, MARIA, and KENNETH HALE. 1996. The structural determination of case and agreement. Linguistic Inquiry 27:1-68.

BobalJiK, Jonathan. 1993. Ergativity and ergative unergatives. Papers on case and agreement II: MIT Working Papers in Linguistics, ed. by Colin Phillips, 45-88.

CENA, RETSY. 1979. Tagalog Counterexamples to the Accessibility Hierarchy. Studies in Philippine Linguistics 31: 119-124.

Guilfoyle, Etthne, Henrietta Hung, and Lisa Travis. 1992. Spec of IP and Spec of VP: Two subjects in Austronesian languages. Natural Language and Linguistic Theory 10: 375-414.

KeEnAN, EDWARD L. 1976. Remarkable subjects in Malagasy. Subject and topic, ed. by Charles Li, 249-301. New York: Academic Press.

Kroeger, PAul. 1993. Phrase structure and grammatical relations in Tagalog. Stanford, CA: CSLI.

LASNIK, HOWARD, and TIM STOWELL. 1991. Weakest crossover. Linguistic Inquiry 22:687-720.

Maclachlan, AnNA. 1996. Aspects of ergativity in Tagalog. McGill University Ph.D. dissertation.

PEARSON, MATT. 2001. The clause structure of Malagasy: A Minimalist approach. UCLA Ph.D. dissertation. 
RICHARDS, NORVIN. 2000. Another look at Tagalog subjects. Formal issues in Austronesian linguistics, ed. by Ileana Paul, Vivianne Phillips, and Lisa Travis, 105-116. Dordrecht: Kluwer.

SCHACHTER, PAUL. 1976. The subject in Philippine languages: Topic, actor, actor-topic, or none of the above? Subject and topic, ed. by Charles Li, 491-518. New York: Academic Press.

SELLS, PETER. 2000. Raising and the order of clausal constituents in the Philippine languages. Formal issues in Austronesian linguistics, ed. by Ileana Paul, Vivianne Phillips, and Lisa Travis. Dordrecht: Kluwer.

TRAVIS, LISA. 1998. Theta-positions and binding in Balinese and Malagasy. Canadian Journal of Linguistics 43: 435-467.

WeChSLER, STEPHEN, and WAYAN ARKA. 1998. Syntactic ergativity in Balinese. Natural Language and Linguistic Theory 16:387-441.

ileana@uwo.ca

lisa.travis@staff.mcgill.ca 